\title{
Karakteristik Dosen dalam Memopulerkan Perguruan Tingginya melalui Facebook dan Twitter
}

\author{
ANNE RATNASARI ${ }^{1}$, YUSUF HAMDAN², AMINUDDIN IRFANI ${ }^{3}$ \\ 1 \& 2 Fakultas Ilmu Komunikasi Unisba, ${ }^{3}$ Fakultas Ekonomi Unisba, \\ Jl. Tamansari No. 1 Bandung

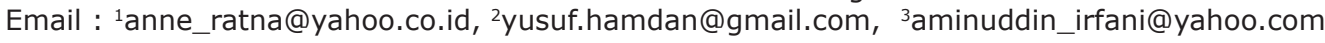

\begin{abstract}
One of the lecturers activities in popularizing college by making posts on facebook and twitter. This article is the result of research that aimed to analyze the character, competence and strength of lecturers in popularizing college via facebook and twitter. Using qualitative research methods, design of case studies. Informants are lecturers Kopertis Region IV West Java - Banten selected as Outstanding Lecturer. The results are, college can be popularized by lecturer through facebook. Lecturers have good character, being able to communicate the vision of college, perceived as a good man, and has a good personality. Lecturers also have competence as a trustworthy person, have a commitment to make a change for the better, able to develop themselves, perceived as people who have the power to maintain their profession well, and can maintain ethics as Outstanding Lecturer. Through twitter, lecturers will get a good response from the public regarding their performance.
\end{abstract}

Keywords : lecturer, college, facebook, twitter

\begin{abstract}
Abstrak. Salah satu aktivitas dosen dalam memopulerkan perguruan tingginya dengan membuat tulisan di facebook dan twitter. Artikel ini merupakan hasil penelitian yang bertujuan menganalisis karakter, kompetensi, dan kekuatan dosen dalam memopulerkan perguruan tingginya melalui facebook dan twitter. Metode penelitian menggunakan kualitatif, desain studi kasus. Informan adalah dosen Kopertis Wilayah IV Jawa Barat - Banten yang terpilih sebagai Dosen Berprestasi. Hasil penelitian menemukan, dosen dapat memopulerkan perguruan tingginya melalui facebook, dosen memiliki karakter yang baik, karena mampu mengomunikasikan visi perguruan tingginya, dipersepsi sebagai orang baik, dan memiliki kepribadian apa adanya. Dosen juga memiliki kompetensi sebagai orang yang dapat dipercaya, mempunyai komitmen membuat perubahan ke arah lebih baik, mampu mengembangkan diri, dipersepsi sebagai orang yang memiliki kekuatan untuk menjalankan profesi dengan baik, dan dapat menjaga etika sebagai Dosen Berprestasi. Melalui twitter dosen mendapat respons yang baik mengenai performa dirinya dari masyarakat.
\end{abstract}

Kata kunci : dosen, perguruan tinggi, facebook, twitter

\section{Pendahuluan}

Aktivitas mengomunikasikan apa yang telah dicapai oleh seseorang, apakah tokoh publik, tokoh politik, dan kalangan lainnya, termasuk dosen, masuk pada salah satu kegiatan komunikasi pemasaran, khususnya merek. Menurut Waringin (2008: 2-4), merek masuk pada aliran mengingatkan.

Dalam konsep merek, terdapat satu kegiatan yang ditujukan untuk mengelola merek perorangan, supaya orang tersebut memiliki citra seperti yang diharapkannya.
Kegiatan tersebut selain dapat dilakukan secara tatap muka, juga dapat menggunakan media sosial seperti facebook dan twitter.

Pengguna facebook di Indonesia ada 43,06 juta orang, tertinggi ketiga di dunia. Pengguna media ini tidak hanya remaja, juga bapak-bapak atau ibu-ibu, dan digunakan antara lain, untuk sarana berbelanja, sedangkan pengguna twitter Indonesia berada di urutan tertinggi kelima di dunia, dengan 19,5 juta pengguna (Supratiwi dalam ANTARANews. 21 Juni 2012). 
Penggunaan media tersebut yang demikian banyak, tidaklah mengherankan karena media sosial mengusung kombinasi antara ruang lingkup elemen dunia maya, dalam produk-produk layanan online seperti blog, forum diskusi, chat room, e-mail, website dan juga kekuatan komunitas yang dibangun pada jejaring sosial (Juju dan Sulianta, 2010: 1).

Dosen sebagai sebuah profesi diatur dalam Undang-Undang no. 14 tahun 2005, "Guru dan dosen mempunyai fungsi, peran, dan kedudukan yang sangat strategis dalam pembangunan nasional dalam bidang pendidikan ..., sehingga perlu dikembangkan sebagai profesi yang bermartabat." Sedangkan pada pasal 1 ayat 2, Undang-Undang ini ditegaskan,

"Dosen adalah pendidik profesional dan ilmuwan dengan tugas utama mentransformasikan, mengembangkan, dan menyebarkan ilmu pengetahuan, teknologi, dan seni melalui pendidikan, penelitian, dan pengabdian kepada masyarakat."

Demikian besar peran dosen, karena kapasitasnya sebagai pribadi yang memiliki pengaruh seperti atau seolah lembaga di masyarakat, mereka mendapat sebutan sebagai institutionalized person.

Dilihat dari aspek pengelolaan merek merupakan kegiatan yang sangat penting bagi dosen dalam memberikan pelayanan kepada sivitas akademika. Karena itu, artikel hasil penelitian ini mengkaji karakteristik dosen dalam memopulerkan perguruan tingginya melalui facebook dan twitter, hal ini karena dosen selain sebagai pendidik yang memiliki kewajiban Tri dharma Perguruan Tinggi, yaitu melakukan Pengajaran, Penelitian, dan Pengabdian kepada masyarakat juga diharapkan memiliki pribadi yang menjadi suri tauladan bagi anak didiknya, khususnya dalam menjalankan profesi sebagai dosen memiliki citra positif, memiliki kapasitas dan kualitas yang baik. Walaupun di lapangan seperti dikemukakan Mitra Djamal, dosen Institut Teknologi Bandung, yang juga reviewer Direktorat Jenderal Pendidikan Tinggi Kemendikbud, ditemukan riset-riset di Perguruan Tinggi Swasta (PTS) masih sangat minim (dalam PRLM, 27 Juli 2012). Riset Indiyati (2012) juga menemukan, penelitian dosen di Kopertis Wilayah IV Jawa Barat belum disebarkan melalui media elektronik.

Artikel ini menjelaskan pendekatan kualitatif digunakan dalam penelitian, dengan studi kasus tunggal (Mulyana, 2002: 201 dan Yin, 2002: 27). Pengumpulan data dilakukan dengan observasi, wawancara mendalam, dan kepustakaan. Penelitian ini menjelaskan upaya dosen memopulerkan perguruan tingginya, karena masyarakat menaruh kepercayaan yang tinggi bahwa dosen memiliki pribadi unggul. Dosen sebagai Informan penelitian adalah dosen Kopertis Wilayah IV Jawa Barat yang terpilih sebagai dosen berprestasi pada 2011.

Kehadiran facebook, dan twitter membawa perubahan pada kehidupan masyarakat. Bob McDougll menjelaskan, Indonesia merupakan salah satu negara pengguna jejaring sosial terbanyak di dunia, jejaring sosial yang banyak digunakan masyarakat di antaranya facebook, dan twitter (mediaindonesia.com, 06 Juni 2010).

Facebook merupakan satu dari media sosial yang dapat dimanfaatkan untuk menambah pertemanan, menulis pengalaman pribadi di dinding (curhat), share informasi (berita) terkini, memperlihatkan foto terbaru (Suswanto, 2009: 19-21). Sedangkan twitter berupa sebuah web dan layanan microblog yang bisa dilakukan untuk melakukan pembaharuan (update) berupa sebuah teks (Juju \& Sulianta, 2010: 175-176).

Karakteristik dosen dalam penelitian ini ditinjau dari aspek karakter, kompetensi, dan kekuatan (kepemimpinan), hal itu merujuk pada pendapat Haroen (2014: 81) yang menjelaskan, kajian dari merek yang berkaitan dengan identitas seseorang dapat ditelaah dari karakter, kompetensi, dan kekuatan (memimpin).

Kotler (2005: 110), dan Sutisna, (2001: 271) berpendapat,

merek adalah nama, istilah, tanda, simbol atau desain, atau kombinasi dari keseluruhannya yang dimaksudkan untuk mengidentifikasi barang atau jasa dari penjual, agar dapat dibedakan dari kompetitornya. Sebuah merek memiliki ekuitas sebesar pengenalan konsumen atas merek tersebut dan menyimpannya dalam memori mereka beserta asosiasi merek yang mendukung, kuat, dan unik (Shimp, 2014: 10; Durianto, 2010: 20). Munculnya teknologi sosial, telah membuat merek tidak hanya lebih personal, namun lebih terjangkau (Schawbel dalam mashable.com, 4 Desember 2012).

Pengelolaan merek (nama) seseorang adalah merek yang disandangnya, merek tersebut disebut positif, antara lain, dapat membangun diferensiasi, membangun posisi, memperkuat persepsi yang tertanam pada orang lain, menjadi jembatan lahirnya kepercayaan, menjadi pesan yang akan menyampaikan pada khalayak bahwa 
kehadiran Anda adalah solusi atau masalah mereka (dalam Haroen, 2014:18). Mengamati merek yang dimiliki seseorang merupakan fenomena menarik. Merek merupakan bagian penting dari marketing. Sebuah merek memiliki atribut yang menggambarkan identitas tertentu. Misalnya, merek Apple diatributkan sebagai teknologi modis dan keren (Enterprise, 2011: 1).

Pada dasarnya, merek seseorang lebih banyak terkait dengan persepsi orang lain terhadap dirinya. Demikian halnya dengan merek yang melekat pada barang atau jasa. Jadi, merek terkait dengan persepsi. Dengan demikian, merek seseorang adalah proses membangun persepsi orang lain tentang diri orang itu. Persepsi lebih penting dari realitas dan seringkali persepsi itu realitas juga (Al Ries dalam Haroen, 2014: 21).

Berdasarkan riset, merek seseorang dan karier yang dimilikinya adalah tanda sebuah merek, tanda ini menonjol sebagai satu ciri keahliannya dalam memenangkan persaingan (Trinidad, yfsmagazine.com, 16 Oktober 2012). Temuan riset Pavlina (StevePavlina.com. 04 Desember 2012) mengemukakan, ketika orang lain berinteraksi dengan Anda, secara otomatis membentuk asosiasi mental yang menghubungkan Anda dengan label tertentu. Ini terjadi secara otomatis karena pikiran kita terhubung untuk membentuk pola dan bentuk asosiasi. Label tersebut melekat dan menjadi bagian dari merek seseorang.

Montoya (2002) mengemukakan,

merek seseorang dibentuk oleh spesialisasi, kepemimpinan, kepribadian, berbasis pada karakter, kompetensi, dan kekuatan (dalam Haroen, 2014:81). Puryear Jr. (2000) mengemukakan karakter merupakan dasar dari suatu kepemimpinan. Setelah karakter barulah pengetahuan. Pengetahuan ini berguna untuk membangun kepercayaan dan keberanian memutuskan. Seorang pemimpin yang sukses adalah orang yang berhasil mengombinasikan antara kualitas karakter, integritas, intelegence, dan kemauan untuk bekerja (Muladi, 2007, dalam Haroen, 2014: 82).

Karakter mengandung arti, antara lain watak, sifat, atau akhlak sehari-hari. Lickona (1991) menjelaskan karakter bisa muncul dari seseorang karena ada yang disebut pemahaman moral, motivasi moral, perilaku moral (dalam Haroen, 2014: 84).

Karakter adalah sumber dari reputasi. Oleh karena itu, pusatkan kekuatan Anda untuk membentuk karakter diri lebih dulu kemudian diikuti dengan proses pemasaran untuk membangun reputasi. Character is what you are, reputation is what people think you are. Karakter adalah diri Anda yang sebenarnya, sedangkan reputasi adalah apa yang dipikirkan orang lain tentang Anda (Purjear Jr., 2000 dalam Haroen, 2014:85).

Wes Weiler (hiredMYway.com.26 Mei 2013), menjelaskan,

untuk mengetahui merek seseorang dapat dilihat dari nilai, semangat, bakat, dan kepribadian. Nilai berkaitan dengan karakter, integritas, etika, dan moralitas. Semangat berhubungan dengan gairah seseorang untuk mengerjakan sesuatu yang menjadi daya dorong untuk segera mewujudkannya. Bakat dimiliki seseorang seperti kreativitas, kemampuan teknis, keuletan, kemampuan membina hubungan, atau kemampuan memimpin. Gibson (hiredMYway.com.26 Mei 2013) mengemukakan, kepribadian mendukung dalam menentukan posisi yang tepat untuk seseorang. Kepribadian ini mencakup introvert, extrovert, pemimpin, atau sebagai pemain tim.

\section{Penggunaan Facebook dan Twitter}

Upaya dosen terpilih sebagai Dosen Berprestasi adalah mereka bekerja dengan ikhlas, memiliki target output yang jelas dan terukur, memiliki komitmen dengan diri sendiri, selalu berupaya melakukan yang terbaik yang dapat dilakukan, setiap tugas dikerjakan dengan serius dan penuh tanggung jawab. Sebagai dosen berusaha semaksimal mungkin untuk dapat menjalankan Tridharma Perguruan Tinggi secara konsisten dan berimbang. Selain itu, dosen memiliki prestasi unggul, misalnya karya ilmiah terpublikasi dalam jurnal internasional bereputasi, karya penelitian yang memiliki kemanfaatan yang tinggi, dan hak kekayaan intelektual.

Dengan demikian jelaslah, informan penelitian sudah selayaknya terpilih sebagai Dosen Berprestasi karena sejumlah aktivitas yang mereka kerjakan dengan optimal, baik yang terkait dengan Tridharma Perguruan Tinggi, maupun aspek lainnya, seperti keharmonisan antara karya dengan hati, sehingga dapat mengerjakan segala sesuatu secara serius, ikhlas, dan terus berkarya menghasilkan karya terbaik.

Penggunaan facebook dan twitter antara lain untuk mendukung kegiatan kampus, memenuhi kebutuhan kemunikasi secara pribadi, dan aktivitas lainnya. Dalam penggunaan facebook, sebagian besar informan memiliki satu account, hanya ada satu orang yang memiliki dua account.

Sebagian besar informan cukup sering menggunakan facebook, hanya sebagian kecil informan yang menggunakannya sangat sering. Informan yang menggunakannya 
cukup sering (1 jam) perhari, karena disesuaikan dengan jenis kepentingannya, dan karena kesibukan bekerja tidak terlalu aktif menuliskan status atau komentar dalam facebook. Informan melakukan setting privacy friends, sehingga facebook dirinya hanya dapat dilihat oleh kawan-kawannya. Adapun aktivitas yang dilakukannya antara lain membaca coment orang lain, menulis coment sendiri, membalas pesan pada inbox, dsb. Informan yang menggunakan facebook antara 2-3 jam setiap hari berpendapat, facebook dimanfaatkan sebagai media komunikasi dengan keluarga, mahasiswa, alumni, kolega, dan masyarakat. Aktivitas informan dalam menggunakan facebook tersebut sesuai dengan pendapat Suswanto (2009: 19-21), di mana facebook antara lain digunakan untuk menambah teman, dan share informasi aktual.

Terdapat satu orang informan yang aktif menggunakan twitter. Twitter dimanfaatkan untuk share informasi, misalnya untuk mendukung aktivitas kuliah, menanggapi peristiwa aktual, dan menginformasikan kegiatan yang akan diselenggarakan. Sebagai contoh, bila ada suatu peristiwa hangat yang sedang terjadi di masyarakat, informan ikut memberi pemikiran dengan mengikuti (follow) twitter orang lain yang dianggap tokoh, atau share informasi kepada mahasiswa tentang suatu peristiwa terkait satu materi dalam kuliah.

Demikian pentingnya media sosial bagi kehidupan masyarakat, pemerintah melalui program Pusat Layanan Internet Kecamatan (PLIK), menyediakan fasilitas internet di mana masyarakat dapat memanfaatkan media tersebut dan masyarakat kini dapat masuk ke dalam jaringan informasi global. Melalui PLIK masyarakat dapat mengakses dan memperoleh berbagai informasi, data, pengetahuan dan jejaring yang tak terbatas (Fardiah, et al., dalam Mimbar, Volume 30, No. 2, 2014).

\section{Karakteristik Dosen dalam Memop- ulerkan Perguruan Tingginya di Face- book dan Twitter}

Dalam memopulerkan perguruan tinggi tempat dosen mengerjakan aktivitas Tridharma Perguruan tinggi, dosen melakukan beberapa kegiatan, baik secara internal maupun eksternal. Secara internal, dosen membuka diri dengan memberi kesempatan untuk berkomunikasi dengan mahasiswa peserta kuliah, atau pihak lain.
Aktivitas dosen antara lain memberi konsultasi bagi mahasiswa dan pihak lain mengenai perkuliahan melalui facebook. Mengenai perkuliahan, misalnya pembahasan suatu topik tertentu, memotivasi mahasiswa, pembahasan tugas-tugas mahasiswa, maupun nonilmiah, seperti informasi penyelenggaraan ujian, dan acara fakultas, koordinasi, dan berbagi info lainnya.

Pada aspek motivasi misalnya, dosen memberi motivasi kepada anak didiknya untuk terus belajar dan berkarya. Pada setiap kesempatan, dosen mengajak anak didiknya untuk mengembangkan kreativitas dan keahliannya. Jika seorang dosen mampu menumbuhkan rasa ingin tahu dalam diri anak didiknya, mereka akan memiliki kesempatan yang lebih baik untuk meraih kesuksesan, kebahagiaan, dan hubungan yang kuat dengan orang lain dalam kehidupan mereka (Fahkruddin, 2012: 83).

\section{Syukur (2011: 40) menjelaskan,}

menjadi dosen yang baik selain memiliki kreativitas yang tinggi, dapat membuat mahasiswa tertarik mengikuti mata kuliahnya, juga mampu membangun hubungan antarpribadi yang baik dengan mahasiswa dan orangtuanya.

Dosen yang sering berkomunikasi dengan mahasiswa, hubungannya menjadi lebih akrab, karena komunikasi interaktif di antara mereka, sehingga dosen terbuka menjadi "teman" mahasiswa. Hal ini sesuai dengan hasil penelitian Ratnasari (dalam Mimbar, Vol. 24, No. 1, 2008), fasilitas internet digunakan untuk selain untuk belajar, juga untuk membangun hubungan sosial.

Dengan demikian dosen memotivasi mahasiswanya untuk mengembangkan kreativitas mereka, mengembangkan kemampuan membina hubungan, atau kemampuan memimpin dengan menyarankan, dan membimbing mahasiswa agar aktif dalam unit-unit kegiatan yang ada di kampus, karena "kesempatan kuliah di kampus sebaiknya tidak hanya diisi dengan kegiatankegiatan akademik. Gunakan masa 3-4 tahun di kampus untuk mengembangkan diri, bakat dan minat, serta berinteraksi sebanyakbanyaknya dengan berbagai kalangan.

Unit kegiatan mahasiswa (UKM) adalah salah satu saluran efektif untuk mengembangkan diri di kampus. Setiap kampus pasti menyediakan beraneka ragam UKM, mulai dari kegiatan penelitian, penalaran, sosial kemasyarakatan, sampai hobi. Banyak tokoh terkenal ternyata meluangkan dirinya mengembangkan bakat saat kuliah. Setelah 
kuliah, mereka malah terbilang sukses dalam bidang yang ditekuninya di unit kegiatan mahasiswa. Salah satunya, aktor Rowan Atkinson atau yang dikenal sebagai Mr. Bean (kompas.com, 30 Januari 2013).

Melalui facebook informan mengekspresikan kemampuan dirinya sebagai seorang dosen, misalnya, saat dosen memiliki penghargaan atas karya ilmiahnya, mendapat apresiasi yang sangat baik dari civitas akademikanya melalui comment temantemannya di facebook. Penjelasan tersebut sesuai dengan pendapat Rahman (2012:48), manfaat facebook untuk menyampaikan informasi, opini, mengekspresikan diri melalui penulisan status, komentar, notes, dan unggah foto.

Tempat informan mengakses kedua media tersebut yaitu di kantor (kampus) menggunakan komputer sendiri melalui modem eksternal dan wifi, di rumah, di perjalanan, di ruang publik, dan ketika diperlukan dengan menggunakan gadget (smartphone dan tablet). Dari penjelasan tersebut terlihat dosen aktif menggunakan facebook dan twitter bertujuan untuk berkomunikasi dengan berbagai pihak, dan memenuhi kebutuhan informasi.

Hal itu sesuai pendapat Baldwin et al. (2004), di mana media sosial digunakan untuk interaksi sosial. Pendapat senada dikemukakan Frankl (dalam Safaria dan Rahardi, 2006:116-117), terdapat tiga pilar filosofis yang penting bagi kehidupan manusia dalam proses pemenuhan kebermaknaan hidup yaitu kebebasan berkehendak (freedom of will), kehendak hidup bermakna (will to meaning), dan makna hidup (meaning of life).

Kebebasan berkehendak itu maksudnya manusia memiliki kebebasan untuk menentukan sikap ketika berhadapan dengan berbagai situasi. Kehendak hidup bermakna mendorong manusia melakukan kegiatankegiatan penting lainnya. Makna hidup memberi pedoman dan arah terhadap kegiatan yang dilakukan, sehingga makna hidup seakan-akan menantang, dan mengundang seseorang untuk memenuhinya.

\section{Karakter Dosen}

Karakteristik dosen penelitian ini diteliti pada aspek karakter, kompetensi, serta kekuatan (memimpin) yang ada pada diri dosen yang disajikan tulisan di facebook. Pada aspek karakter kepada informan ditanyakan tentang aktivitasnya ketika apakah menggunakan facebook mengomunikasikan visi perguruan tinggi tempat mereka bekerja, dipersepsi sebagai orang yang baik oleh orang lain, dan memiliki kepribadian apa adanya. Karakter informan, pertama, sebagian besar informan selalu mengomunikasikan visi perguruan tinggi tempat mereka bekerja, hanya sebagian kecil dari mereka yang kadang-kadang mengomunikasikan visi Perguruan Tinggi tempat mereka bekerja.

Kedua, informan dipersepsi sebagai orang baik. Alasannya adalah menggunakan facebook sebagai sarana berkomunikasi dengan orang-orang yang sudah dikenal sebelumnya, dan biasanya kontak dilakukan secara pribadi, dan berasumsi setiap orang yang mau kontak dengan dirinya, tentu orang tersebut menganggap dirinya sebagai orang yang baik. Informan dipersepsi sebagai orang baik, artinya informan memiliki moralitas yang baik. Hal itu sesuai dengan pendapat Weiler (dalam hiredMyway.com, 26 Mei 2013), mengenai pendukung merek (nama) seseorang yaitu karakter, integritas, etika, dan moralitas. Pendapat Weiler diperkuat oleh Puryear (2000) (dalam Haroen, 2014: 8), yang menjelaskan karakter sebagai watak, sifat, dan dasar suatu kepemimpinan. Karakter adalah diri kita yang sebenarnya. Penelitian mengenai karakter, dilakukan Smith (dalam abjusa.com, 20 April 2013), hasilnya menemukan bahwa semakin karismatik seorang CEO, semakin baik performa perusahaan, sekitar $10-15 \%$ lebih baik.

Contoh yang relevan tentang karakter dosen, seperti yang ditulis salah satu informan yang menulis status di facebook berikut: "April 1989-April $2014=25$ tahun pengabdian di Kampus Jingga". Tulisan informan mendapat respons positif dari teman-teman di facebook, dalam bentuk jumlah like yang cukup banyak (63 buah) dan komentar positif. Contoh lain, informan menulis status mengenai motivasi dengan disertai literasi Al-Quran, juga mendapat komentar positif dari banyak pihak.

Pada contoh tersebut terungkap, informan melayani pihak lain dengan hati yang tulus, Borg (2014: 28) berpendapat, ketulusan hati penting jika ingin mengembangkan empati yang didasarkan pada kepercayaan. Jika Anda menunjukkan ketulusan hati dengan jujur, Anda sedang meningkatkan diri Anda pada derajat yang lebih tinggi. Kepercayaan tersebut muncul dalam hubungan. Semakin Anda mendukung orang lain, semakin 
orang itu menunjukkan pemikiran, ide, dan perasaan kepada Anda. Devito (2013: 62) mengungkapkan pendapat yang mendukung, kita membuka diri lebih banyak kepada orang yang kita percayai.

Ketiga, kepribadian dosen, dosen memiliki kepribadian apa adanya ketika berkomunikasi melalui facebook. Mereka berkomunikasi dengan keadaan sebenarnya. Kepribadian dosen tersebut diapresiasi secara baik oleh orang lain ketika berkomunikasi melalui facebook, sehingga hal itu menjadi nilai tambah bagi perguruan tingginya karena performa dosen yang demikian bersahaja. Mahasiswa menilai kepribadian dosen dalam mengajar baik, dan hubungan dosen dan mahasiswa juga baik. Agar dosen dapat terus mempertahankan, bahkan meningkatkan kepribadian yang baik, dosen perlu pengembangan diri, antara lain pada aspek soft skill. Soft skill adalah kemampuan seseorang dalam berhubungan dengan orang lain (interpersonal skill) dan keterampilan dalam mengatur dirinya sendiri (intrapersonal skill) yang mampu mengembangkan unjuk kerja secara maksimal. Contoh soft skill antara lain kemampuan beradaptasi, komunikasi, kepemimpinan, pengambilan keputusan, pemecahan masalah, conflict resolution, dan lain sebagainya.

Manfaat soft skill antara lain bersifat mandiri, membangun karakter, membangun kepribadian yang berkualitas, menumbuhkan rasa percaya diri, mampu bersosialisai dalam tim, menumbuhkan kepekaan wawasan pemikiran, dan membentuk jiwa yang kritis di dalam diri individu (Kompas.com, 20 Agustus 2012).

Sistem pendidikan kita memberikan pendidikan kebanyakan hard skill dan sedikit pendidikan soft skill. Pembinaan soft skill di perguruan tinggi dilakukan melalui proses pembelajaran dan kegiatan ekstra kurikuler serta ko-kurikuler. Pembinaan soft skill melalui proses pembelajaran, menuntut dosen bisa berperan secara optimal. Peran tersebut mulai dari perilaku dosen, metode pembelajaran, dan mengoptimalkan substansi mata kuliah yang diampu (kompas.com, 20 Agustus 2012).

Penjelasan informan sejalan dengan pendapat Borg (2014: 31), di mana orang yang berhasil memengaruhi secara positif, sehingga dapat memengaruhi pikiran audience secara baik. Hal ini sesuai dengan pendapat Montoya (2002) (dalam Haroen, 2014: 67), seseorang memunyai kepribadian apa adanya memiliki sifat yang baik.

Dosen menggunakan kata-kata yang diucapkan di dunia nyata dan di facebook dan twitter cenderung sama. hal itu tercermin dari sikap dosen yang bersikap dan berperilaku sama saat berkomunikasi di dunia nyata dengan di kedua media sosial tersebut. Dosen peduli dan berkewajiban membantu orang lain. Bentuknya diwujudkan dalam diskusi mengenai hal tersebut, dan memberi masukan kepada orang lain untuk berkata, berbicara dengan kata-kata yang baik dan penuh manfaat. Contoh, dosen yang melayani pelatihan kepada stakeholder, perguruan tinggi, selalu berusaha menjawab dengan cepat, setiap pertanyaan dan konsultasi baik dari mahasiswa maupun masyarakat umum terkait dengan persoalan yang dihadapi mereka. Contoh lainnya, jika ada mahasiswa yang memasang status kurang baik, maka informan sebagai dosen merasa wajib mengingatkan mahasiswa tersebut agar memperbaiki statusnya.

Penjelasan tersebut sesuai dengan pendapat Borg (2014:56), jika ingin pesan kita disimak dengan baik oleh pendengar kita, maka kita pun harus membuat pendengar tertarik untuk menyimak. Salah satu caranya dengan memilih kata yang baik dengan cara antara lain, pilihlah kata-kata secara hati-hati.

Ahli psikolinguistik, sebuah cabang psikologi yang mempelajari perilaku verbal, mengamati bagaimana kita menggunakan bahasa, dan bagaimana kemampuan verbal berinteraksi dengan kemampuan kognitif lainnya- bagaimana kata-kata dapat memengaruhi pikiran dan emosi kita. Bahasa dapat memengaruhi pikiran, dan kata-kata adalah adalah alat untuk menciptakan citra (image) secara mental (Borg, 2014: 159). Selanjutnya Borg (2014: 34),

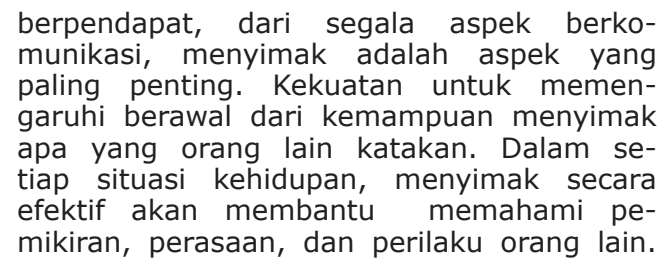

\section{Kompetensi Dosen}

Kompetensi dimaknai sebagai pengetahuan, keterampilan, dan nilai-nilai dasar yang direfleksikan dalam kebiasaan berpikir dan bertindak. Kompetensi dapat pula dimaksudkan sebagai kemampuan melaksanakan tugas yang diperoleh melalui pendidikan dan atau latihan (Herry, 1998 
dalam Haroen, 2014).

Kompetensi merupakan syarat utama yang harus dimiliki oleh seseorang. Kompetensi adalah 'isi' dari produk (person) yang akan 'dijual'. Jika diibaratkan dengan kecantikan seorang gadis, maka kompetensi adalah 'inner beauty' atau 'kecantikan hakiki' yang dimiliki seseorang yang diinformasikan ke khalayak (dalam Haroen, 2014:93).

Kompetensi dosen ditelaah dari aspek kedapatdipercayaan informan, memiliki komitmen membuat perubahan ke arah lebih baik, dan memiliki kemampuan untuk mengembangkan diri menjalankan profesi sebagai dosen. Penelitian menemukan dosen dinilai sebagai pribadi yang dapat dipercaya, ketika berkomunikasi melalui facebook. Hal ini karena informan sangat menjaga integritas yang merupakan salah satu kunci sukses dalam menjalin komunikasi dan hubungan baik dengan siapa pun. Sebagai contoh, informan mendapat apresiasi yang sangat baik dari salah satu kliennya.

Dari kata-kata yang disusun dalam status tersebut terlihat, orang yang menulis hal itu sebagai orang baik, karena dia memiliki keinginan yang kuat ingin agar orang lain tahu, dan bisa mengikuti acara tersebut. Selain itu facebook sebagai alat bantu untuk berkomunikasi dengan orang-orang yang sudah dikenal sebelumnya, tentunya dalam komunikasi, orang-orang tersebut menganggap dirinya sebagai orang yang dapat dipercaya.

Informan memiliki komitmen membuat perubahan ke arah lebih baik dalam menjalankan profesinya sebagai dosen. Misalnya, berkomitmen berbagi kepada mahasiswa, dan masyarakat dengan menyebarkan tulisan, artikel, penelitian ilmiah maupun modul-modul kuliah. Selain itu, juga memiliki motivasi menjadi manusia yang patuh, semangat mencari dan berbagi ilmu, senantiasa bersedekah dan jadikan Al-Quran sebagai sumber utama literasi. Mengamati aktivitas informan tersebut, dia telah berhasil memadukan aktivitas kedunian dan keakheratan dengan berimbang.

Aspek lainnya, informan memiliki kemampuan mengembangkan diri sebagai dosen. Kemampuan berkomunikasi lisan dan tulisan informan menjadi terasah dan terlatih lebih baik dengan menggunakan facebook dan twitter. Selain itu, informan dapat memperoleh banyak kesempatan untuk mengedukasi dan memotivasi masyarakat agar kuat dan semangat dalam berkarya, namun tetap patuh akan norma dan agama.

\section{Kekuatan (Memimpin) Dosen}

Dosen dipersepsi sebagai orang yang memiliki kekuatan untuk menjalankan profesi dengan baik sebagai dosen ketika berkomunikasi melalui facebook dan twitter. Tulisan dosen di facebook berisi pengetahuan, pengalaman, dan prestasi dosen, sehingga melalui tulisan tersebut memberikan kekuatan bagi dirinya dalam berkomunikasi dengan orang lain. Tulisan dosen pada wall (dinding) facebook isinya membahas tentang keahlian dosen terlihat pada Gambar 1 berikut.

Pada dinding facebook tersebut dijelaskan tulisan informan mengenai topik sesuai keahlian dalam bidang ilmunya, yaitu bidang keuangan mikro, khususnya tentang praktik keuangan mikro yang berlaku di dunia. Adapun tujuan informan menulis di dinding facebook antara lain, ingin berbagi kepada orang lain. Contohnya, hasil riset yang bersifat kaku menjadi lentur dengan bahasa gaul, untuk berdiskusi tentang penelitian dan pengabdian kepada masyarakat yang sedang dilaksanakan, dan untuk menginspirasi serta memotivasi rekan dosen juga mahasiswa agar secara berkelanjutan melaksanakan penelitian dan pengabdian dimulai dari hal yang paling mudah dan mampu dikerjakan.

Contoh lainnya, ketika seorang informan berhasil meraih penghargaan sebagai "The Best Paper \& Presenter Award" pada sebuah konferensi di Jepang, dia menuliskan status di dinding facebook mengenai capaian tersebut, dan statusnya mendapat banyak like dan komentar positif. Informan lainnya menjelaskan ketika memasang status atau mengomentari status senantiasa dikaitkan dengan proses pembelajaran berpikir dan berperilaku yang lebih komprehensif baik melalui jalur formal atau pun informal, dengan pendekatan Islami yaitu merujuk sumber yang maha benar, yakni Al-Qur'an.

Selain itu, informan dapat menjaga etika sebagai dosen berprestasi ketika berkomunikasi melalui facebook, karena kata-kata yang ditulis di facebook akan terbaca oleh siapa pun, sehingga informan berhati-hati dalam menulis. Karena itu informan memasang status dan memberi komentar status yang berisi motivasi dan menggugah agar senantiasa berpikir, berucap, berperilaku dan menginspirasi sesuai dengan Al-Qur'an. 
Hal itu sesuai dengan pendapat Santosa (2010: 121), di mana dalam menjalankan suatu profesi memerlukan kekuatan berkomitmen, konsisten, dan upaya yang terus-menerus, sehingga dapat mencapai tujuan. Sedangkan konsistensi memberikan kredit tersendiri dalam dunia pendidikan, sebab ia menjadi alat pijak keberhasilan pembelajaran (Fakhruddin, 2012:106). Pendapat lainnya dikemukakan Zaccaro (2004, dalam Haroen, 2014:86), di mana seorang pendidik harus memiliki kecerdasan dalam hal kemampuan berbicara, bernalar, dan menafsirkan lebih kuat. Kedua, percaya diri yakni memiliki keyakinan akan kompetensi, keahlian, dan harga diri. Ketiga jujur, di mana pendidik dapat dipercaya. Keempat, determinatif adalah hasrat menyelesaikan pekerjaan seperti inisiatif, gigih, dapat memengaruhi, dan mengarahkan. Kelima, interaktif di mana pendidik dapat menjalin hubungan yang menyenangkan dengan individu lainnya.

Pesan yang ditulis dalam twitter, sesuai dengan keahlian informan yaitu pada bidang keuangan mikro contoh pesannya, "... menjadi orang mapan secara finansial adalah mimpi setiap orang, berikut alasan mengapa tabungan kita tak kunjung meningkat...., tulisan lainnya "...pengeluaran berlebih dan gaya hidup yang konsumtif dapat memperkecil tabungan kita...", atau informasi perkuliahan buat mahasiswa, misalnya "...tugas Kelayakan Bisnis dikumpulkan tanggal....". Penggunaan twitter memberi peluang besar untuk membantu upaya promosi, contohnya, "...ingin meningkatkan kemampuan melihat peluang bisnis? Ikuti training..... Dari contoh tersebut terlihat aktivitas informan menggunakan twitter antara lain, untuk berbagi informasi, seperti tips yang mengingatkan orang dalam menggunaan uang, dan informasi kegiatan kuliah, juga training.

Para aktivis twittter dapat dilakukan perorangan atau oleh lembaga. Bagi lembaga diperlukan tim yang terdiri dari orang yang benar-benar mengerti menggunakan twitter, dan yang paling penting adalah orang ini suka dengan aktivitas nge-tweet (Pudyastomo, 2009:11-12). Twitter merupakan sebuah web dan layanan microblog yang bisa dilakukan untuk melakukan pembaharuan berupa teks dengan panjang maksimum 140 karakter. Pembaruan di twitter dikenal sebagai tweets. Pembaruan yang dibuat bisa dilihat orang lain yang menjadi follower (pengikut), dan seseorang juga bisa melihat pembaharuan orang lain yang diikuti (follow) (Antara News, 21 Juni 2012).

Aktivitas informan dalam menggunakan twitter tersebut sesuai dengan pendapat Juju \& Sulianta (2010:176) di mana pengguna dapat menuliskan aktivitas yang sedang

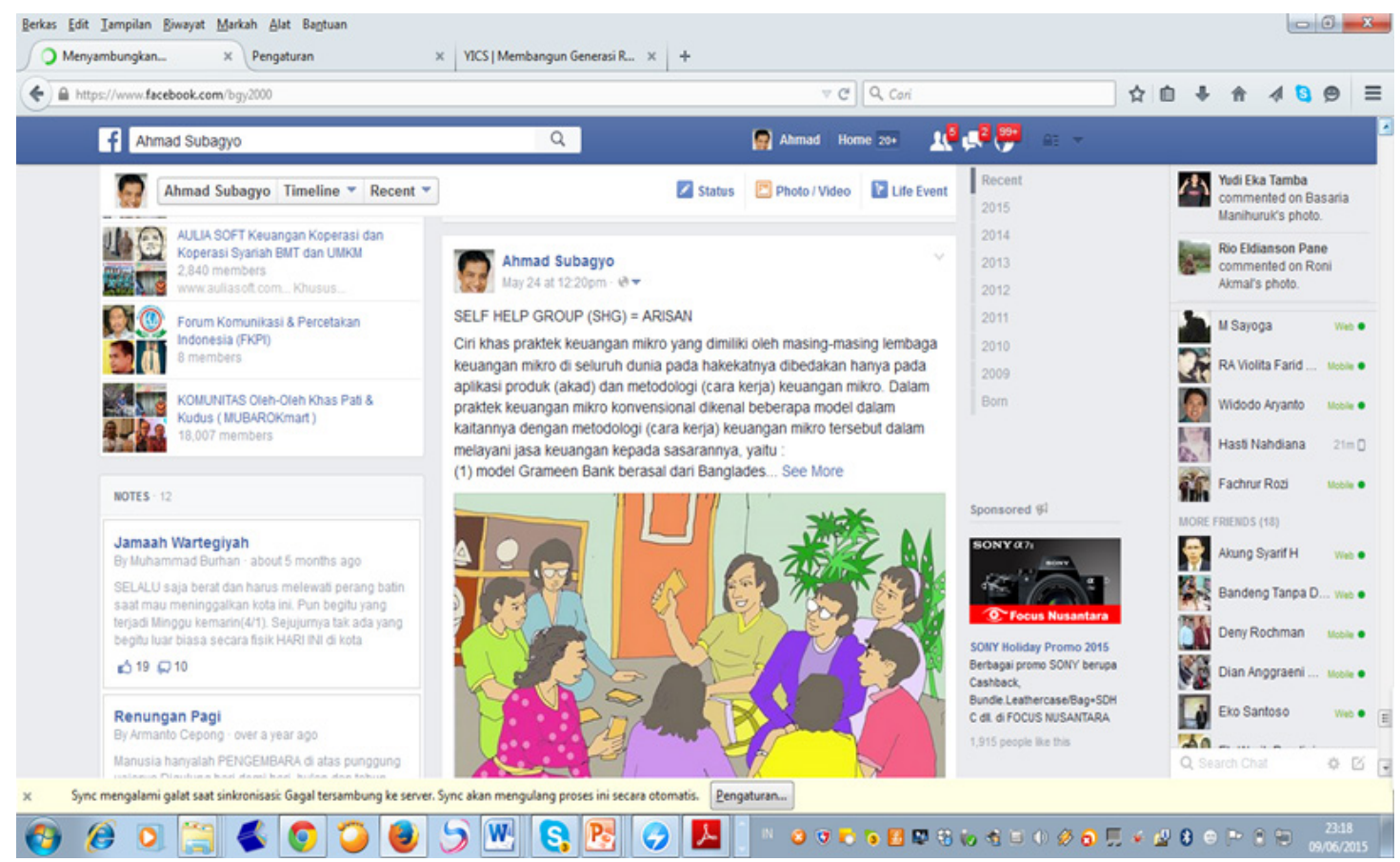

Gambar 1

Informasi tentang Keahlian Dosen yang Ditulis di Dinding Facebook 
Tabel 1

Karakteristik Dosen dalam Memopulerkan Perguruan Tingginya Melalui Facebook dan Twitter

\begin{tabular}{|l|l|l|}
\hline No & Karakteristik Dosen & Uraian \\
\hline 1 & Karakter & $\begin{array}{l}\text { a. Mengomunikasikan visi Perguruan Tinggi. } \\
\text { b. Dipersepsi sebagai orang baik. } \\
\text { c. Memiliki kepribadian apa adanya. }\end{array}$ \\
\hline 2 & Kompetensi & $\begin{array}{l}\text { a. Dapat dipercaya. } \\
\text { b. Memiliki komitmen membuat perubahan ke arah lebih baik. } \\
\text { c. Memiliki kemampuan mengembangkan diri. }\end{array}$ \\
\hline 3 & Kekuatan (Memimpin) & $\begin{array}{l}\text { a. Dipersepsi sebagai orang yang memiliki kekuatan untuk } \\
\text { menjalankan profesi dengan baik. } \\
\text { b. Menjaga etika sebagai dosen berprestasi. }\end{array}$ \\
\hline
\end{tabular}

Sumber : Data penelitian

dilakukannya dan memanfaatkannya untuk mempromosikan produk atau layanan jasa, karena twitter memiliki keunikannya tersendiri (Rahman, 2012: 53).

Seperti diketahui dosen memiliki reputasi yang sangat baik di bidangnya, sehingga calon klien, dan klien menaruh minat yang besar untuk mendapat ilmu dari mereka dengan memintanya sebagai trainer atau konsultasi bisnis. Karena itu informan sebagai dosen, konsultan, juga trainer sering sekali diundang menjadi dosen tamu, penceramah, atau memberi materi dalam training yang berhubungan dengan bidangnya.

Informan juga menyadari dengan memanfaatkan twitter dapat mengetahui respons klien dan masyarakat mengenai performanya. Manfaat menggunakan twitter antara lain, nama (merek) dirinya meningkat seiring dengan aktivitasnya dalam berbagai event, yang ditunjang dengan melakukan up date informasi di media sosial. Hogan (2007: 255) menjelaskan orang membuat berbagai keputusan, sebagai besar karena kepercayaan.

Tulisan mengenai informasi, dan pengalaman dosen di facebook dan twitter tersebut, memberikan kekuatan kepadanya baik dalam bernegosiasi maupun memengaruhi orang lain. Menurut Hamdan, et al., (dalam Mimbar, Vol. 29, No.2, 2013), seseorang yang pandai bernegosiasi untuk membangun kerjasama dengan pihak lain seperti membuat suatu pelatihan, event, dan acara lainnya, hal itu karena dia memiliki karakteristik personal sebagai negosiator cukup kuat, mampu menggunakan pesan verbal secara jelas, singkat, dan bermakna positif.
Dengan demikian, aktivitas dosen mengelola facebook dan twitter, memudahkan mahasiswa, dan pihak lainnya untuk mendapatkan informasi atau bentuk pelayanan lainnya, sehingga aktivitas tersebut membuat diri informan lebih dikenal, baik sebagai dosen, konsultan dan pembicara publik, dan pada gilirannya memopulerkan perguruan tingginya.

\section{Simpulan dan Saran}

Kesimpulan mengenai karakteristik dosen dalam memopulerkan perguruan tingginya melalui facebook, pertama, dosen aktif menggunakan facebook dan twitter. Dosen memiliki karakter yang mendukung tugasnya sebagai dosen, dengan cara mengomunikasikan visi perguruan tingginya, dipersepsi sebagai orang yang baik, dan memiliki kepribadian apa adanya. Kedua, dalam berkomunikasi menggunakan facebook dosen memiliki kompetensi yang baik, informasi yang disampaikannya dapat dipercaya, memiliki komitmen membuat perubahan ke arah lebih baik, dan mampu mengembangkan diri dengan baik. Ketiga, dosen memiliki kekuatan dalam memimpin dengan baik, di mana dosen dipersepsi sebagai orang yang memiliki kekuatan untuk menjalankan profesi, dan dapat menjaga etika sebagai dosen berprestasi. Informan pengguna twitter menyediakan waktu untuk melakukan up date terus-menerus. Twitter dimanfaatkan dosen sebagai media internal yang digunakan untuk menunjang kuliah, sebagai media eksternal untuk menginformasikan dan mempromosikan dirinya sebagai konsultan dan pembicara publik. 
Saran untuk dosen agar lebih memanfaatkan facebook dan twitter untuk terus mempublikasikan kemampuan, dan capaiannya, sehingga memiliki nama positif yang mempopulerkan perguruan tingginya. Kedua, Media sosial yang paling intensif digunakan dosen adalah facebook dibandingkan twitter, karena itu disarankan agar dosen dapat memadukan penggunaan media sosial tersebut untuk meningkatkan merek mengenai dirinya menjadi lebih baik.

Ketiga, aktivitas dosen dalam memopulerkan perguruan tingginya melalui facebook dan twitter tidak ada kendala yang berarti. Dalam meningkatkan popularitas perguruan tinggi, akan lebih baik jika pihak perguruan tinggi memberikan pelatihan khusus terkait fasilitas media sosial, sehingga dosen dapat mengelola merek dirinya menjadi lebih baik.

\section{Daftar Pustaka}

Baldwin, J.R., Perry, S.D., \& Moffit, M.A. (2004), Communication Theories for Everyday Life. Boston: Pearson Education Inc.

Borg, James. (2014), Persuasion. Terj. Dewi R.S. Jakarta: Daras Books.

DeVito, Josep A. (2013), The Interpersonal Communication Book.Boston : Pearson Education Inc.

Durianto, et al. (2001). Strategi Menaklukkan Pasar: Melalui Riset Ekuitas dan Perilaku

Merek. PT Gramedia Pustaka Utama, Jakarta.

Enterprise, Jubilee. (2011). Personal Branding Lewat Internet. Jakarta: PT Elex Media Komputindo.

Fakhruddin Asef Umar. (2012). Menjadi Guru Favorit!. Yogyakarta : Diva Press.

Fardiah, D., Rinawati, R. \& Kurniadi, O. (2014). Optimalisasi PLIK (Pusat Layanan Internet Kecamatan) Dalam Meningkatkan Aksesibilitas Masyarakat Terhadap Informasi. Mimbar, Vol. 30, No. 2, hal. 243-252.

Haroen, Dewi. (2014). Personal Branding: Kunci Kesuksesan Berkiprah di Dunia Politik. Jakarta: PT. Gramedia Pustaka Utama.

Hogan, Kevin. (2007). The Science of Influence: Bagaimana memengaruhi Orang lain Waktu Singkat. Jakarta: PT Elex Media Komputindo-Gramedia.

Gibson, Nathan S. "Personal Branding with Social Media". HiredMyWay.com. 26 Mei 2013.

Indiyati, Dian. (2012). Pengembangan Penyebaran Pengetahuan pada Perguruan Tinggi Swasta Kopertis Wilayah IV. Prosiding Seminar nasional penelitian dan PKM (SnaPP) : Sosial, Ekonomi, dan Humaniora. Vol. 3, No. 1, hal. 27-34.
Juju, Dominikus, dan Sulianta, Feri. (2010). Branding Promotion With Social Network. Jakarta: PT Elex Media Komputindo.

Kompas.com. Pendidikan Kunci Pembangunan. 20 Agustus 2012.

Kompas.com. Rowan "Mr Bean" Atkonson Kembali ke Panggung Teater. 30 Januari 2013.

Kotler. Philip. (2005). Manajemen Pemasaran. Jilid 2. Jakarta: PT. Indeks Kelompok Gramedia.

mediaindonesia.com. "Indonesia Pengguna Jejaring Sosial Terbanyak di Dunia". 06 Juni 2010.

Hamdan, Y., Ratnasari, A. \& Hirzi, A.T. (2013). Profil Negosiator Bisnis Wanita pengusaha. Mimbar, Vol. 29, No. 2, hal. 235-245.

Mulyana, Deddy. (2002). Metode Penelitian Kualitatif. Bandung: PT. Remaja Rosdakarya.

Pavlina, Steve. StevePavlina.com. "Personal Branding". 04 Desember 2012.

PRLM. Dosen PTS Jarang Lakukan Aktivitas Riset. 27 Juli 2012.

Pudyastomo, Yulius Andre, (2009). Langsung Bisa Pake Twitter, Yogyakarta: Mediakom.

Rahman, Su. (2012). Internet Marketing. Jakarta: PT Elex Media Komputindo.

Ratnasari, Anne (2008). Internet sebagai Media Penunjang Studi Mahasiswa. Mimbar, Vol. 24, No. 1, hal. 13-28.

Shimp, Terence A. (2014). Periklanan Promosi. Jakarta: Erlangga.

Safaria, Triantoro \& Rahardi, Kunjana. (2006). Menjadi Pribadi Berprestasi. Jakarta: Grasindo.

Santosa. Eko Jalu. (2010). Good Ethos: 7 Etos Kerja terbaik dan Mulia. Jakarta: PT. Gramedia.

Schawbel, Dan. "Personal Branding 101: How to Discover and Create Your Brand." mashable.com. 4 Desember 2012.

Smith, Shannon. "The Personal Brand Revolution." abjusa.com. 20 April 2013.

Suswanto, Shaven S. (2009). Mendulang Uang di Facebook. Jakarta: Cyan Publisher.

Sutisna.(2001). Komunikasi Pemasaran dan Perilaku Konsumen. PT Remaja Rosdakarya, Bandung.

Syukur, Freddy Faldi. (2011). Menjadi Guru Dasyat, Guru yang memikat. Bandung: Simbiosa Rekatama Media.

UU No. 14 Tahun 2005 tentang Guru dan Dosen.

Waringin, Tung Desem. (2008). Marketing Revolution. Jakarta : PT Gramedia Pustaka Utama.

Weiler, Wes. "Personal Branding with Social Media". HiredMyWay.com. 26 Mei 2013.

Trinidad, Alexis. yfsmagazine.com. "3 Personal branding and Social media Predictions that will Impac your Small Business". 16 Oktober 2012.

Yin, Robert K. (2002). Studi Kasus. Jakarta: Raja Grafindo. 